\title{
Gonadotropin-inhibitory hormone in Gambel's white-crowned sparrow (Zonotrichia leucophrys gambelii): cDNA identification, transcript localization and functional effects in laboratory and field experiments
}

\author{
T Osugi ${ }^{1,2}$, K Ukena ${ }^{1,2}$, G E Bentley ${ }^{3}$, S O$^{\prime}$ Brien $^{3}$, I T Moore ${ }^{3}$, \\ J C Wingfield ${ }^{3}$ and $K$ Tsutsui ${ }^{1,2}$ \\ 'Laboratory of Brain Science, Faculty of Integrated Arts and Sciences, Hiroshima University, Higashi-Hiroshima 739-8521, Japan \\ ${ }^{2}$ Core Research of Evolutional Science and Technology (CREST), Japan Science and Technology Corporation, Tokyo 150-0002, Japan \\ ${ }^{3}$ Department of Biology, University of Washington, Seattle, Washington 98195, USA \\ (Requests for offprints should be addressed to K Tsutsui, Laboratory of Brain Science, Faculty of Integrated Arts and Sciences, Hiroshima University, \\ Higashi-Hiroshima 739-8521, Japan; Email: tsutsui@hiroshima-u.ac.jp)
}

\begin{abstract}
The neuropeptide control of gonadotropin secretion is primarily through the stimulatory action of the hypothalamic decapeptide, GnRH. We recently identified a novel hypothalamic dodecapeptide with a C-terminal LeuPro-Leu-Arg-Phe- $\mathrm{NH}_{2}$ sequence in the domestic bird, Japanese quail (Coturnix japonica). This novel peptide inhibited gonadotropin release in vitro from the quail anterior pituitary; thus it was named gonadotropininhibitory hormone $(\mathrm{GnIH})$. GnIH may be an important factor regulating reproductive activity not only in domesticated birds but also in wild, seasonally breeding birds. Thus, we tested synthetic quail GnIH in seasonally breeding wild bird species. In an in vivo experiment, chicken gonadotropin-releasing hormone-I (cGnRH-I) alone or a cGnRH-I/quail GnIH cocktail was injected i.v. into non-breeding song sparrows (Melospiza melodia). Quail $\mathrm{GnIH}$ rapidly (within $2 \mathrm{~min}$ ) attenuated the GnRHinduced rise in plasma LH. Furthermore, we tested the effects of quail $\mathrm{GnIH}$ in castrated, photostimulated Gambel's white-crowned sparrows (Zonotrichia leucophrys gambelii), using quail $\mathrm{GnIH}$ or saline for injection. Again, quail GnIH rapidly reduced plasma $\mathrm{LH}$ (within $3 \mathrm{~min}$ ) compared with controls. To characterize fully the action of GnIH in wild birds, the identification of their endogenous $\mathrm{GnIH}$ is essential. Therefore, in the present study a cDNA encoding GnIH in the brain of Gambel's white-crowned sparrow was cloned by a combination of $3^{\prime}$ and $5^{\prime}$ rapid amplification of cDNA ends and compared with the quail GnIH cDNA previously identified. The deduced sparrow
\end{abstract}

GnIH precursor consisted of 173 amino acid residues, encoding one sparrow GnIH and two sparrow GnIHrelated peptides (sparrow GnIH-RP-1 and GnIH-RP-2) that included Leu-Pro-Xaa-Arg-Phe- $\mathrm{NH}_{2}(\mathrm{Xaa}=\mathrm{Leu}$ or $\mathrm{Gln})$ at their C-termini. All these peptide sequences were flanked by a glycine C-terminal amidation signal and a single basic amino acid on each end as an endoproteolytic site. Although the homology of sparrow and quail GnIH precursors was approximately $66 \%$, the C-terminal structures of GnIH, GnIH-RP-1 and GnIH-RP-2 were all identical in two species. In situ hybridization revealed the cellular localization of sparrow GnIH mRNA in the paraventricular nucleus (PVN) of the hypothalamus. Immunohistochemical analysis also showed that sparrow GnIH-like immunoreactive cell bodies and terminals were localized in the PVN and median eminence respectively. Thus, only the sparrow PVN expresses GnIH, which appears to be a hypothalamic inhibitory factor for LH release, as evident from our field injections of $\mathrm{GnIH}$ into free-living breeding white-crowned sparrows. Sparrow GnIH rapidly (within $2 \mathrm{~min}$ ) reduced plasma $\mathrm{LH}$ when injected into free-living Gambel's white-crowned sparrows on their breeding grounds in northern Alaska. Taken together, our results indicate that, despite amino acid sequence differences, quail $\mathrm{GnIH}$ and sparrow GnIH have similar inhibitory effects on the reproductive axis in wild sparrow species. Thus, GnIH appears to be a modulator of gonadotropin release.

Journal of Endocrinology (2004) 182, 33-42

\section{Introduction}

In vertebrates, the neuropeptide control of gonadotropin secretion is primarily through the stimulatory action of the hypothalamic decapeptide, gonadotropin-releasing hormone $(\mathrm{GnRH})$. Although gonadal steroids are known to be a negative factor for the regulation of gonadotropin secretion, until recently an inhibitory neuropeptide 
of gonadotropin secretion had not been identified in vertebrates.

We recently identified a novel hypothalamic neuropeptide inhibiting gonadotropin release in the Japanese quail (Coturnix japonica), a domestic bird, and termed it gonadotropin-inhibitory hormone $(\mathrm{GnIH})$ (Tsutsui et al. 2000). This is the first hypothalamic neuropeptide inhibiting gonadotropin release in a vertebrate. This neuropeptide is a dodecapeptide containing a C-terminal Leu-Pro-LeuArg-Phe- $\mathrm{NH}_{2}$ sequence, SIKPSAYLPLRF-NH $\mathrm{NH}_{2}$ (Tsutsui et al. 2000) and cell bodies and terminals containing this neuropeptide were localized in the paraventricular nucleus (PVN) and median eminence (ME) respectively (Tsutsui et al. 2000, Ubuka et al. 2003, Ukena et al. 2003). More recently, we further cloned a cDNA encoding the GnIH precursor polypeptide in the quail brain (Satake et al. 2001). Interestingly, the $\mathrm{GnIH}$ precursor polypeptide encoded one GnIH and two GnIH-related peptides (GnIH-RP-1 and GnIH-RP-2) that included Leu-Pro$\mathrm{Xaa}-\mathrm{Arg}-\mathrm{Phe}-\mathrm{NH}_{2}(\mathrm{Xaa}=\mathrm{Leu}$ or Gln$)$ at their C-termini (Satake et al. 2001). The GnIH mRNA was also expressed only in the PVN (Satake et al. 2001, Ukena et al. 2003).

Based upon our previous studies (Tsutsui et al. 2000, Satake et al. 2001, Ubuka et al. 2003, Ukena et al. 2003), GnIH may be an important factor for the regulation of avian reproduction. To understand the physiological role of $\mathrm{GnIH}$ in avian reproduction, wild avian species may serve as excellent animal models. Gambel's white-crowned sparrow (Zonotrichia leucophrys gambelii) is one of the most obligately photoperiodic species of seasonally breeding wild birds (Farner \& Mewaldt 1955, Farner 1964, 1975, King et al. 1966, Wingfield \& Farner 1978, 1993). Seasonal changes and photoperiodic control of the secretion of gonadotropins have been well established in this bird (King et al. 1966, Farner 1975, Wingfield \& Farner 1993, Wingfield \& Silverin 2002). In the present study, we therefore identified and characterized a cDNA encoding sparrow $\mathrm{GnIH}$ in the brain of the white-crowned sparrow to elucidate the presence of sparrow GnIH. Here we describe the white-crowned sparrow GnIH cDNA sequence and the localization of sparrow GnIH mRNA in the hypothalamus via in situ hybridization. In addition, we describe the in vivo anti-gonadotropic effect of synthetic white-crowned sparrow GnIH when injected into freeliving Gambel's white-crowned sparrows on their breeding grounds in northern Alaska. We compare this effect with the effects of injections of quail GnIH into laboratoryhoused white-crowned sparrows and song sparrows (Melospiza melodia), another photoperiodic wild bird species.

\section{Materials and Methods}

The experimental protocol of all experiments (Experiments 1-4) was approved in accordance with the NIH
Guide for the Care and Use of Laboratory Animals, and with the approval of the Animal Care and Use Committee of University of Washington (USA) and Hiroshima University (Japan).

Experiment 1: in vivo demonstration of rapid inhibition of luteinizing hormone (LH) release by exogenous quail $\mathrm{GnIH}$ in song sparrows

Photorefractory male song sparrows ( $n=7$ per group) were used for this experiment. Photorefractory birds were used so that we could control the amount of $\mathrm{GnRH}$ given to each bird (eliminating any confounding effects of endogenous GnRH). The pituitary gland of photorefractory birds remains responsive to exogenous $\mathrm{GnRH}$ even though little or no endogenous $\mathrm{GnRH}$ is released in this reproductive condition (Wingfield et al. 1979, Nicholls et al. 1988, Dawson et al. 2001). Group I (control) was given an i.v. injection (into the right jugular vein) of $10 \mathrm{ng}$ chicken gonadotropin-releasing hormone-I (cGnRH-I) in $20 \mu \mathrm{l}$ physiological (0.9\%) saline. Group II (experimental) was given an i.v. injection of a mixture of $10 \mathrm{ng} \mathrm{GnRH}$ plus $1000 \mathrm{ng} \mathrm{GnIH}$ in $20 \mu \mathrm{l}$ physiological saline. Blood samples were taken from the alar vein at 2, 5 and $10 \mathrm{~min}$ after injection. This protocol has been used previously to demonstrate rapid gonadotropin-releasing activity of GnRH in songbirds (e.g. Wingfield et al. 1979, Wingfield \& Farner 1993).

Experiment 2: in vivo demonstration of rapid inhibition of LH release by exogenous quail GnIH in castrated Gambel's white-crowned sparrows

Twelve adult male white-crowned sparrows were captured in Central Washington during their fall migration. Thus, they were in non-breeding condition (photorefractory) with small testes, facilitating castration. To remove feedback effects of gonadal steroids on LH release, birds were bilaterally castrated under isofluorane anesthesia (4\%) using curved forceps inserted through an incision below the last pair of ribs. The birds were then transferred to short, winter-like photoperiods of $8 \mathrm{~h}$ light and $16 \mathrm{~h}$ darkness (8 L:16 D) for 132 days to induce full photosensitivity (ability of the reproductive axis to increase gonadotropin release in response to long day lengths). At this point, the birds were transferred to a long, spring-like photoperiod (16 L:8 D) for 7 days to induce high plasma LH. Half of the birds were then injected i.v. with $500 \mathrm{ng}$ quail GnIH in $20 \mu$ l physiological saline, and the other half with saline alone. Blood was collected from the alar vein at 1,3 and $10 \mathrm{~min}$ post-injection. In this experiment we sampled blood 1 min earlier than in Experiment 1, as we saw an effect of quail $\mathrm{GnIH}$ injection at $2 \mathrm{~min}$ in that experiment (see Results section). Thus we were able to determine if i.v. quail GnIH effects on plasma $\mathrm{LH}$ were evident sooner than $2 \mathrm{~min}$. 
Experiment 3: identification of a cDNA encoding white-crowned sparrow $\mathrm{GnIH}$

Adult Gambel's white-crowned sparrows were used for the identification of a cDNA encoding sparrow GnIH. In situ hybridization of sparrow GnIH mRNA and immunohistochemical analysis of $\mathrm{GnIH}$ were carried out in the brains of adult females, because there was no sex difference in the distribution of $\mathrm{GnIH}$ in the quail brain (Tsutsui et al. 2000, Ubuka et al. 2003, Ukena et al. 2003). Birds were housed in outdoor aviaries exposed to naturally changing photoperiod, and tissues were harvested in mid-October. At this time of year, this species becomes photosensitive, a condition which allows the reproductive axis to respond to increasing day lengths in the spring. In this way, full reproductive maturity is attained at the appropriate time of year.

\section{$R N A$ preparation and amplification of the partial sparrow $\mathrm{GnIH}$ cDNA fragments}

Total RNA of the diencephalon was extracted with Sepazol-RNA I Super (Nacalai Tesque, Kyoto, Japan) in accordance with the manufacturer's instructions. All PCR amplifications were performed in a reaction mixture containing Taq polymerase (Ex Taq polymerase (Takara Shuzo, Kyoto, Japan) or gene Taq polymerase (Nippon Gene, Tokyo, Japan)) and $0.2 \mathrm{mM}$ dNTP on a thermal cycler (Program Temp Control System PC-700; ASTEC, Fukuoka, Japan). First-strand cDNA was synthesized with the oligo(dT)-anchor primer supplied in the $5^{\prime} / 3^{\prime}$ rapid amplification of cDNA ends (RACE) kit (Roche Diagnostics, Basel, Switzerland) and amplified with the anchor primer (Roche Diagnostics) and the first degenerate primers $5^{\prime}-\mathrm{GCIAA}(\mathrm{T} / \mathrm{C})(\mathrm{T} / \mathrm{C}) \mathrm{TICCI}(\mathrm{T} / \mathrm{C}) \mathrm{TI}(\mathrm{C} /$ A)GITT(T/C)GG-3' (I represents inosine), corresponding to the quail GnIH-RP-1 sequence Ala-Asn ${ }^{7}-\mathrm{Leu}^{8}$ -

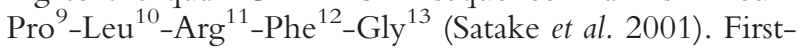
round PCR products were reamplified with the second degenerate primers 5'-AT(A/T/C)AA(A/G)CCIAG(T/ C) GCITA $(\mathrm{T} / \mathrm{C})(\mathrm{T} / \mathrm{C}) \mathrm{TICC}-3^{\prime}$, corresponding to the quail GnIH sequence $\mathrm{Ile}^{2}-\mathrm{Lys}^{3}-\mathrm{Pro}^{4}-\mathrm{Ser}^{5}-\mathrm{Ala}^{6}-\mathrm{Tyr}^{7}-$ Leu $^{8}$-Pro ${ }^{9}$ and $5^{\prime}-(\mathrm{T} / \mathrm{C})$ TTICC $(\mathrm{A} / \mathrm{G}) \mathrm{AAIC}(\mathrm{G} / \mathrm{T})(\mathrm{T} /$ C)TGIGGIA-3', complementary to the quail GnIHRP-2 sequence Leu ${ }^{9}-$ Pro $^{10}-\mathrm{Gln}^{11}-\mathrm{Arg}^{12}-\mathrm{Phe}^{13}-\mathrm{Gly}^{14}$ Lys $^{15}$ (Tsutsui et al. 2000, Satake et al. 2001). Both first-round and second-round PCRs consisted of 30 cycles of $30 \mathrm{~s}$ at $94{ }^{\circ} \mathrm{C}, 30 \mathrm{~s}$ at $45^{\circ} \mathrm{C}$, and $1 \mathrm{~min}$ at $72{ }^{\circ} \mathrm{C}(10 \mathrm{~min}$ for the last cycle). The second-round PCR products were subcloned into a pGEM-T Easy vector in accordance with the manufacturer's instructions (Promega, Madison, WI, USA). The DNA inserts of the positive clones were amplified by PCR with universal M13 primers.

\section{Determination of the $3^{\prime}$-end sequence of sparrow $\mathrm{G} n I H \mathrm{cDNA}$}

First-strand cDNA was synthesized as described above and amplified with the anchor primer and gene-specific primer 1 (5'-CCATTTTCAAATTTGCCCCT-3', corresponding to nt 359-378); this was followed by further amplification of the first-round PCR products with the anchor primer and gene-specific primer 2 (5'-GGAA GAGCTTTTGGAGAGAA-3', corresponding to nt 386405). Both first-round and second-round PCRs were performed for 30 cycles consisting of $1 \mathrm{~min}$ at $94^{\circ} \mathrm{C}$, $1 \mathrm{~min}$ at $55^{\circ} \mathrm{C}$, and $1 \mathrm{~min}$ at $72^{\circ} \mathrm{C}(10 \mathrm{~min}$ for the last cycle). The second-round PCR products were subcloned and the inserts were amplified as described above.

Determination of the $5^{\prime}$-end sequence of sparrow $\mathrm{GnIH}$ cDNA

Template cDNA was synthesized with an oligonucleotide primer complementary to nt 452-471 (5'-CTGGAA CCTTTAACAAGTGG-3'); this synthesis was followed by dA-tailing of the cDNA with dATP and terminal transferase (Roche Diagnostics). The tailed cDNA was amplified with the oligo(dT)-anchor primer and genespecific primer 3 (5'-TTAACAAGTGGAGATCTCTC$3^{\prime}$, complementary to nt 443-462); this was followed by further amplification of the first-round PCR products with the anchor primer and gene-specific primer $4\left(5^{\prime}-\right.$ CAAGCCTGTGTGATACCCTT-3', complementary to nt 424-443). Both first-round and second-round PCRs were performed for 30 cycles consisting of $1 \mathrm{~min}$ at $94{ }^{\circ} \mathrm{C}$, $1 \mathrm{~min}$ at $55^{\circ} \mathrm{C}$, and $1 \mathrm{~min}$ at $72{ }^{\circ} \mathrm{C}(10 \mathrm{~min}$ for the last cycle). The second-round PCR products were subcloned and the inserts were amplified as described above.

\section{DNA sequencing}

All nucleotide sequences were determined with a Thermo Sequenase cycle sequencing kit (Amersham Pharmacia Biotech, Aylesbury, Bucks, UK), IRDye 800 termination mixes version 2 (NEN Life Science Products, Boston, MA, USA), and a model 4200-1 G DNA sequencing system and analysis system (LI-COR, Lincoln, NE, USA), then analyzed with DNASIS-MAC software (Hitachi Software Engineering, Kanagawa, Japan). Universal M13 primers or gene-specific primers were used to sequence both strands.

\section{In situ hybridization of sparrow $\mathrm{G} n \mathrm{IH} m \mathrm{mNA}$}

The site of sparrow GnIH mRNA expression in the brain was localized via in situ hybridization. In brief, adult female sparrows were deeply anesthetized before transcardial perfusion with PBS ( $\mathrm{pH} 7 \cdot 3$ ) followed by fixative solution (4\% paraformaldehyde in PBS). After dissection from the skull, the brains were soaked in a refrigerated sucrose solution (30\% sucrose in PBS) until they sank. The brains were embedded in OCT compound (Miles Inc., Elkhart, IN, USA) and frozen-sectioned frontally at $10 \mu \mathrm{m}$ thickness on a cryostat at $-20{ }^{\circ} \mathrm{C}$. The sections were placed onto 3-aminopropyltriethoxysilane-coated slides. In situ 
hybridization was carried out according to our previous method (Ukena et al. 1999, 2003, Sawada et al. 2002a,b) using the digoxigenin (DIG)-labeled antisense RNA probe. The DIG-labeled antisense RNA probe was produced with RNA labeling kit (Roche Diagnostics) from a part of the peptide precursor cDNA (complementary to nt 313-525). Control for specificity of the in situ hybridization of the peptide mRNA was performed using the DIG-labeled sense RNA probe, which is complementary to the antisense probe sequence.

\section{Immunohistochemistry}

Immunohistochemical analysis was performed using the antiserum against quail $\mathrm{GnIH}$ raised in a rabbit as described previously (Tsutsui et al. 2000, Ukena \& Tsutsui 2001, Koda et al. 2002, Ukena et al. 2003). In brief, anesthetized adult female sparrows were perfused with PBS (pH 7.3) followed by fixative solution (4\% paraformaldehyde in PBS). The frontal sections (10 $\mu \mathrm{m}$ thickness) were cut on a cryostat at $-20{ }^{\circ} \mathrm{C}$ and placed onto 3 -aminopropyltriethoxysilane-coated slides. After nonspecific binding components had been blocked, the sections were immersed with the anti-quail GnIH serum at a dilution of $1: 1000$ overnight at $4{ }^{\circ} \mathrm{C}$ and subsequently with rhodamine-conjugated goat anti-rabbit IgG. The specificity of the staining was assessed by a substitution of the control serum for the antiserum; in this control serum, the antiserum (1:1000 dilution) was pre-absorbed by incubation with the antigen in a saturating concentration $(10 \mu \mathrm{g} \mathrm{GnIH} / \mathrm{ml})$ overnight at $4{ }^{\circ} \mathrm{C}$ before use. Immunoreactive cell bodies and fibers in the sparrow brain were studied using a Nikon fluorescence microscope.

Experiment 4: in vivo field injection of synthetic sparrow GnIH into breeding white-crowned sparrows

Sparrow GnIH with the deduced amino acid sequence SIKPFSNLPLRF-NH $\mathrm{NH}_{2}$ (see Results section) was synthesized and used for i.v. injections. Based on results from Experiments 1 and 2, we chose to use sparrow GnIH at doses of $500 \mathrm{ng}$ (low dose) and $1000 \mathrm{ng}$ (high dose) per $20 \mu$ total injection volume. The vehicle solution was $0.9 \%$ saline.

All injections took place between 15 and 18 June 2003 at the Toolik Field Station in the northern foothills of the Brooks Range in northern Alaska $\left(68^{\circ} 37^{\prime} \mathrm{N}, 149^{\circ} 36^{\prime} \mathrm{W}\right)$. At this time, birds are arriving on their breeding grounds and establishing territories in preparation for breeding. Plasma LH is typically high during this period of the breeding life-history stage. Birds were captured in mist nets using conspecific song playback. Birds were removed from the nets and saline or GnIH of either dose was injected into the jugular vein within $3 \mathrm{~min}$ of capture. Blood $(\sim 100 \mu \mathrm{l})$ was subsequently drawn from the alar vein at 2 and $10 \mathrm{~min}$ post-injection, using a 26-gauge

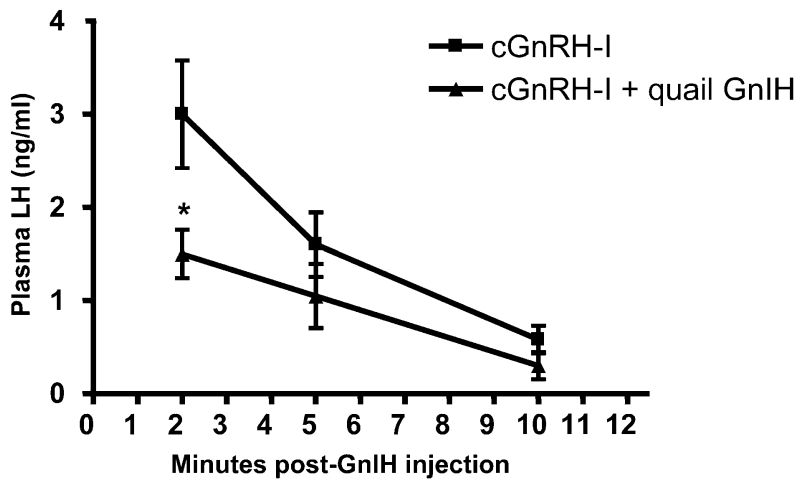

Figure 1 The effects of intra-jugular injection of quail $\mathrm{GnlH}$ on $\mathrm{GnRH}$-elicited $\mathrm{LH}$ release in photorefractory male song sparrows. Note that plasma LH was lower in the GnRH+GnlH group than in the control $(\mathrm{GnRH}$ alone) group at 2 min post-injection. ${ }^{*} P<0.05 \mathrm{GnRH}$ alone vs GnRH $+\mathrm{GnIH}$ by ANOVA, followed by Fisher's PLSD for post-hoc analysis.

needle and heparinized capillary tubes. Plasma was then separated via centrifugation and stored at $-20{ }^{\circ} \mathrm{C}$ until assayed for LH. We obtained samples from six salineinjected birds, five $1000 \mathrm{ng} \mathrm{GnIH}$-injected birds, and two $500 \mathrm{ng} \mathrm{GnIH}$-injected birds. The latter were not included in the statistical analysis because of the small sample size, but the LH data gathered from these individuals are included in the results graph (see Fig. 7).

\section{RIA for $L H$}

Plasma was assayed for LH using the homologous chicken LH RIA (Follett et al. 1972), and validated for songbirds (Dawson \& Goldsmith 1982). Included in the RIA were samples of known LH concentration spiked with $1000 \mathrm{ng}$ $\mathrm{GnIH}$ to check for cross-reactivity with the LH antiserum. No such cross-reactivity was detected in this assay (data not shown). All samples for each experiment were run in duplicate in a single assay.

\section{Statistical analysis}

Assay data were analyzed using repeated-measures ANOVA, with injection type as a between-subjects factor and time as a within-subjects factor, followed by Fisher's protected least square differences (PLSD) test for post-hoc analysis.

\section{Results}

Experiment 1: antagonistic effect of exogenous quail GnIH on chicken gonadotropin-releasing hormone-I in photorefractory song sparrows

The LH data from Experiment 1 are shown in Fig. 1. ANOVA indicated a significant interaction of time and 


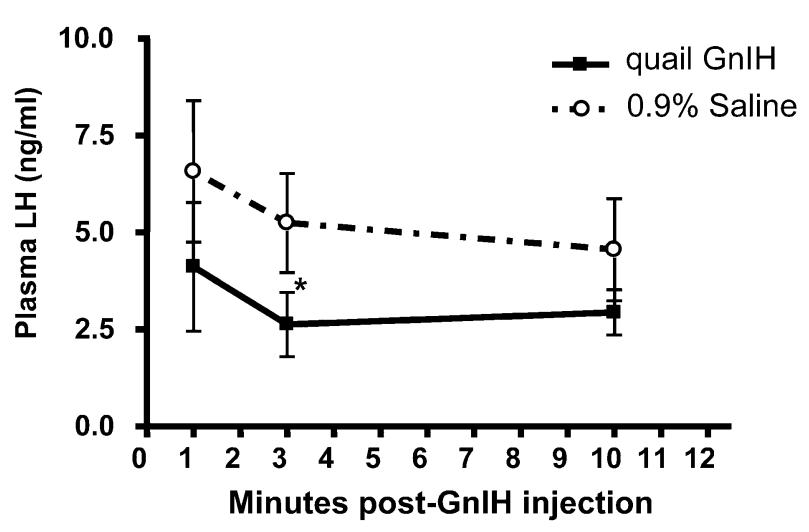

Figure 2 The effects of intra-jugular injection of quail $\mathrm{GnlH}$ on plasma LH in photostimulated, castrated Gambel's white-crowned sparrows. Plasma LH was lower in the GnlH-injected group at 3 min but at no other time. ${ }^{*} P<0.05 \mathrm{GnlH}$ vs vehicle by ANOVA, followed by Fisher's PLSD for post-hoc analysis.

injection (ANOVA: $\mathrm{F}=7 \cdot 293(1,16) ; P=0 \cdot 006)$, allowing for post-hoc analysis to highlight at which time points injections had different effects. At 2 min post-injection, birds injected with $\mathrm{GnRH}$ alone had higher plasma $\mathrm{LH}$ at 2 min than at 10 min (Fisher's PLSD; $P<0 \cdot 001$ ). Birds injected with the GnRH/GnIH cocktail also had elevated plasma LH at $2 \mathrm{~min}$ post-injection (Fisher's PLSD; $P<0 \cdot 05)$, but this increase in $\mathrm{LH}$ was much attenuated compared with the control group (Fisher's PLSD; $P<0 \cdot 05)$. The difference in plasma $\mathrm{LH}$ concentration between the two groups was no longer present at 5 and 10 min post-injection, by which time plasma LH had returned to baseline values in both groups.

Experiment 2: anti-gonadotropic effect of exogenous quail GnIH on LH in castrated Gambel's white-crowned sparrows

The LH data from Experiment 2 are shown in Fig. 2. ANOVA indicated a significant interaction of time and injection (ANOVA: $F=3.481$ (1, 11); $P<0.05)$. Plasma $\mathrm{LH}$ was high in both groups at $1 \mathrm{~min}$ post-injection. By 3 min post-injection, GnIH caused a significant decrease in plasma LH (Fisher's PLSD; $P<0 \cdot 05$ ). By $10 \mathrm{~min}$ post-injection this difference was not still present, mainly due to increased variance of plasma LH in the salineinjected group.

Experiment 3.1: characterization of a $\mathrm{cDNA}$ encoding sparrow GnIH precursor polypeptide

In an attempt to obtain $\mathrm{GnIH}$ precursor polypeptide cDNA fragments from the brain of the white-crowned sparrow, we initially performed an RT-PCR experiment with degenerate primers corresponding to the partial quail GnIH-RP-1 sequence $\mathrm{Ala}^{6}-\mathrm{Asn}^{7}-\mathrm{Leu}^{8}-\mathrm{Pro}^{9}-\mathrm{Leu}^{10}$-Arg ${ }^{11}$ $\mathrm{Phe}^{12}-\mathrm{Gly}^{13}$ and the anchor primer, which was followed by reamplification of the first-round PCR products with degenerate primers corresponding to the partial quail $\mathrm{GnIH}$ sequence $\mathrm{Ile}^{2}-\mathrm{Lys}^{3}-\mathrm{Pro}^{4}-\mathrm{Ser}^{5}-\mathrm{Ala}^{6}-\mathrm{Tyr}^{7}-\mathrm{Leu}^{8}-\mathrm{Pro}^{9}$ and complementary to the partial quail GnIH-RP-2 sequence $\mathrm{Leu}^{9}-\mathrm{Pro}^{10}-\mathrm{Gln}^{11}-\mathrm{Arg}^{12}{ }^{2}-\mathrm{Phe}^{13}-\mathrm{Gly}^{14}-\mathrm{Lys}^{15}$. Electrophoresis of the nested PCR mixture revealed a major product of approximately $0.2 \mathrm{~kb}$ (results not shown). The predicted amino acid sequence included one copy of the putative sparrow GnIH sequence, SIKPFSNLPLRF. To determine the entire sparrow GnIH precursor sequence, we performed $3^{\prime}$-RACE and 5'-RACE with specific primers for the clone. A single product of approximately $0.6 \mathrm{~kb}$ for $3^{\prime}$-RACE or $0.5 \mathrm{~kb}$ for $5^{\prime}$-RACE was obtained and sequenced. Figure 3 shows that the deduced sparrow $\mathrm{GnIH}$ precursor polypeptide encoded one sparrow $\mathrm{GnIH}$ and two sparrow GnIH-related peptides (sparrow GnIHRP-1 and GnIH-RP-2) that included LPXRF (X=L or Q) at their C-termini. The sparrow $\mathrm{GnIH}$ precursor cDNA was composed of 917 nt containing a short 5' untranslated sequence of $40 \mathrm{bp}$, a single open reading frame of $522 \mathrm{bp}$, and a $3^{\prime}$ untranslated sequence of $355 \mathrm{bp}$ with a poly(A) tail. The open reading frame region began with a start codon at position 41 and terminated with a TGA stop codon at position 560 . The nucleotide sequence data reported will appear in DDBJ, EMBL and GenBank Nucleotide Sequence Databases under the accession number AB128164.

Experiment 3·2: comparison of the structures of $\mathrm{GnIH}$ precursor polypeptide, GnIH and GnIH-RPs among the sparrow, quail and chicken

In this study, we identified a cDNA encoding GnIH and GnIH-RPs in the brain of the white-crowned sparrow. We originally identified a cDNA encoding GnIH and GnIH-RPs in the quail brain (Satake et al. 2001). Subsequently, a cDNA encoding GnIH and GnIH-RPs was also reported in the chicken as a gene database (GenBank, accession numbers AB120325 and BAC87781). Therefore, we compared the structures of $\mathrm{GnIH}$ precursor polypeptide, GnIH and GnIH-RPs among the sparrow, quail and chicken. Figure 3 shows the comparison of the structure of $\mathrm{GnIH}$ precursor polypeptide among the sparrow, quail and chicken. Sparrow GnIH precursor polypeptide had approximately $66 \%$ identity with quail GnIH precursor polypeptide. On the other hand, chicken GnIH precursor polypeptide had approximately 95\% identity with quail GnIH precursor polypeptide. Figure 4 further shows the comparison of the structures of $\mathrm{GnIH}$ and GnIH-RPs among three avian species. Identical residues in each peptide are printed white on black. As shown in Fig. 4, sparrow GnIH had 75\% identity with quail GnIH and $67 \%$ identity with chicken GnIH. Sparrow GnIH-RP-1 had 73\% identity with quail and chicken GnIH-RP-1. Sparrow GnIH-RP-2 had 61\% identity with quail and chicken GnIH-RP-2. The identities of 


\begin{tabular}{|c|c|c|}
\hline Sparrow & MKVISTKKFILFALATVVFLTSNSMCLNEAMKSRLQSREDNDDKDYEI & 48 \\
\hline Quail & MEIISTQKFILLTLATVAFLTPHGACLDELMKSSLESREDDDDKYYET & 48 \\
\hline Chicken* & MEVISTQKFILLTLATVAFLTPHGMCLDELMKSSLESREEDDDKYYEI & 48 \\
\hline Sparrow & KDN I LEEKQR SLNEEEMEDWGSKDI I KMNPFTASKMPNSVANLPLREG & 96 \\
\hline Quail & KDS I LEEKQR S LNEEEMKDWGSKNFMKVNT PTVNKVPNSVANLP LREG & \\
\hline Chicken* & $\begin{array}{c}\text { KDS I LEEKQR SLNFEEMKDWGSKNFLKVNTPTVNKVPNSVANLPLREG } \\
\text { GnIH-RP-1 }\end{array}$ & \\
\hline Sparrow & RNYPEER SIKPFSNLPLRFGRAFGENTPNHSPRVSHRLER SPLVKGSS & 144 \\
\hline Quail & RSNPEERSIKPSAYLPLRF GRAFGESLSRRAPNLSNRSGRSPLARSSI & 144 \\
\hline \multicolumn{2}{|r|}{ GnIH } & 144 \\
\hline Sparrow & QSLLNLPQREGKSLAVNLPRDIQEFEPGI & 173 \\
\hline Quail & QSLLNLPQRF GKSVPISLSQGVQESEPGM & 173 \\
\hline Chicken* & $\frac{\text { QSLLNLPQREGKSVP INLSQGVQESEPGM }}{\text { GnIH-RP-2 }}$ & 173 \\
\hline $\begin{array}{l}\text { Figure } 3 \text { Com } \\
\text { chicken. Puta } \\
\text { mature endog } \\
\text { and quail Gnl } \\
\text { site may serve } \\
\text { GenBank (acc }\end{array}$ & $\begin{array}{l}\text { nof the structure of GnIH precursor polypeptide among the sparrow, quai } \\
\text { quences of GnIH, GnIH-RP-1 and GnIH-RP-2 are boxed. Shaded residues } \\
\text { peptides previously identified; quail GnIH (SIKPSAYLPLRF-NH }{ }_{2} \text {, Tsutsui et } \\
\text { (SSIQSLLNLPQRF-NH }{ }_{2} \text {, Satake et al. 2001). Glycine preceding the C-term } \\
\text {-terminal amidation signal. }{ }^{*} \text { Chicken GnlH precursor polypeptide is cited } \\
\text { numbers AB120325, BAC87781). }\end{array}$ & \\
\hline
\end{tabular}

$\mathrm{GnIH}$ and GnIH-RPs between the sparrow and quail were lower than those between the chicken and quail. However, all GnIH and GnIH-RPs in the sparrow, quail and chicken contained a C-terminal LPXRF $(\mathrm{X}=\mathrm{L}$ or Q) motif (Fig. 4).

Experiment 3·3: cellular localization of sparrow GnIH $m R N A$ in the brain

In situ hybridization of sparrow GnIH mRNA was examined in the brain of the white-crowned sparrow by using an RNA probe with a sequence complementary to that of the sparrow GnIH precursor mRNA. An intense expression of sparrow GnIH mRNA was detected only in the PVN in the hypothalamus (Fig. 5a and c). The control study using the sense RNA probe resulted in the complete absence of the sparrow GnIH mRNA expression in the PVN (Fig. 5b and d), suggesting that the reaction was specific for sparrow GnIH mRNA. Cellular localization of $\mathrm{GnIH}$ was further analyzed in the serial section by immunohistochemistry using the anti-quail GnIH serum. As shown in Fig. 6a, immunoreactive cell bodies were also restricted to the PVN. In addition, immunoreactive fibers were emanating from immunoreactive PVN cells (Fig. 6a) and terminated in the $\mathrm{ME}$ and other brain regions (see Bentley et al. 2003). A complete absence of such an immune reaction in the PVN cells was observed by preincubation of the antiserum with synthetic GnIH (Fig. 6b).

Experiment 4: anti-gonadotropic effects of synthetic sparrow GnIH on LH in field-injected white-crowned sparrows

Repeated-measures ANOVA indicated a significant effect of treatment upon plasma LH $(\mathrm{F}=13.63 \quad(1,10)$; $P<0 \cdot 005)$. Birds that were injected with $1000 \mathrm{ng} \mathrm{GnIH}$ had significantly lower plasma $\mathrm{LH}$ at $2 \mathrm{~min}$ than the saline-injected group (Fisher's PLSD; $P<0 \cdot 01$ ). At 2 min post-injection, the same pattern was seen in the birds injected with $500 \mathrm{ng} \mathrm{GnIH}$, but the sample size in this group was too small for statistical analysis. In contrast, saline-injected birds had high plasma LH $(\sim 5 \mathrm{ng} / \mathrm{ml})$ $2 \mathrm{~min}$ post-injection. At $10 \mathrm{~min}$, plasma $\mathrm{LH}$ in the saline group showed no significant change from the $2 \mathrm{~min}$ values. These results are summarized in Fig. 7.

\section{Discussion}

Experiment 1 confirms previous data that GnRH rapidly elicits LH release from song sparrow pituitary in vivo (Wingfield et al. 1979, Wingfield \& Farner 1993). More pertinent to the present study is that the data clearly 


\begin{tabular}{|c|c|c|}
\hline Sparrow GnIH & SIKPFSN & LPLRF $-\mathrm{NH}_{2}$ \\
\hline Quail GnIH & SIKPSAY & LPLRF $-\mathrm{NH}_{2}$ \\
\hline Chicken $\mathrm{GnIH}^{*}$ & 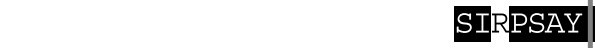 & LPLRF $-\mathrm{NH}_{2}$ \\
\hline Sparrow GnIH-RP-1 & SLNFEEMEDWGSKDIIKMNPFTASY & $\mathrm{LPLRF}-\mathrm{NH}_{2}$ \\
\hline Quail GnIH-RP-1 & SLNFEEMKDWGSKNFMKVNTPTVNKVPNSVAN & LPLRF $-\mathrm{NH}_{2}$ \\
\hline Chicken GnIH-RP-1* & SLNFEEMKDWGSKNFLKVNTPTVNKVPNSVAN & LPLRF $-\mathrm{NH}_{2}$ \\
\hline Sparrow GnIH-RP-2 & SPLVKGSSQSLLN & $\mathrm{LPQRF}-\mathrm{NH}_{2}$ \\
\hline Quail GnIH-RP-2 & SSIQSLLN & $\mathrm{LPQRF}-\mathrm{NH}_{2}$ \\
\hline Chicken GnIH-RP-2* & SSIQSLLN & $-\mathrm{NH}_{2}$ \\
\hline
\end{tabular}

Figure 4 Comparison of the structures of $\mathrm{GnIH}$ and GnIH-RPs among the sparrow, quail and chicken. Identical residues of GnlH, GnIH-RP-1 and GnlH-RP-2 are printed white on black. The C-terminal LPXRF (X=L or Q) motif of each peptide is boxed. ${ }^{*}$ Chicken $\mathrm{GnlH}$, GnlH-RP-1 and GnlH-RP-2 are cited from GenBank (accession numbers AB120325, BAC87781).

demonstrate rapid (within $2 \mathrm{~min}$ ) reduction by quail GnIH of this GnRH-elicited LH release. Experiment 2 demonstrates a rapid effect of quail GnIH on plasma LH in castrated, photostimulated white-crowned sparrows. The results from the injection experiments confirm that $\mathrm{GnIH}$ has in vivo anti-gonadotropic activity in the laboratory and in a field setting. Furthermore, these experiments demonstrate that quail GnIH, SIKPSAYLPLRF-NH $\mathrm{N}_{2}$, has heterospecific anti-gonadotropic effects, reducing plasma LH in song sparrows and white-crowned sparrows. As this paper describes the identification of white-crowned sparrow GnIH cDNA, its transcript and peptide, it was thus important to determine a functional role for this peptide. Putative white-crowned sparrow GnIH, SIKPFSNLPLRF-NH $\mathrm{N}_{2}$, also reduced plasma $\mathrm{LH}$ in wild birds captured on their breeding grounds. An additional feature of this experiment was that GnIH has not previously been used in a field environment. The field environment may be an important feature of this experiment if endogenous GnIH is affected by captivity or stress. Indeed, plasma LH is typically lower in captive wild bird species than in the wild, hence our need for castration or GnRH treatment to elevate plasma LH for the laboratory studies described in this paper. Taken together, it seems that exogenous $\mathrm{GnIH}$ acts within a small window of time, somewhere between $1 \mathrm{~min}$ and $5 \mathrm{~min}$ of administration. It is as yet unclear how GnIH exerts its effects in terms of receptor binding and downstream processing, or competition with $\mathrm{GnRH}$ for binding sites; nor is it known exactly where GnIH is acting. It may be that GnIH only acts at the level of the anterior pituitary gland (Tsutsui et al. 2000). Alternatively, GnIH could act by inhibiting GnRH release from $\mathrm{GnRH}$ fiber terminals in the ME, in addition to acting at the level of the pituitary. The most parsimonious explanation for the rapid attenuation by $\mathrm{GnIH}$ of a GnRH injection-elicited LH rise is its action upon the pituitary gland, as the pituitary of photorefractory birds is also responsive to exogenous GnRH, but this does not negate the possibility of inhibitory action at multiple levels and over different time-frames. Overall, the data from this series of experiments confirm the previous in vitro demonstration of gonadotropin-inhibitory activity by $\mathrm{GnIH}$ (Tsutsui et al. 2000), extending those findings to in vivo activity.

In this study, molecular cloning of cDNA encoding the precursor polypeptide of $\mathrm{GnIH}$ was attempted in the brain of the white-crowned sparrow, a seasonally breeding wild bird. Interestingly, analysis of the resulting cDNA revealed that the sparrow $\mathrm{GnIH}$ precursor encoded one putative sparrow GnIH and two putative gene-related peptide sequences (sparrow GnIH-RP-1 and GnIH-RP-2) that were invariably equipped with $\operatorname{LPXRF}(\mathrm{X}=\mathrm{L}$ or $\mathrm{Q})$ at their C-termini. The structure of sparrow $\mathrm{GnIH}$ precursor cDNA was similar to that of the Japanese quail, a domesticated bird, which also encoded one quail $\mathrm{GnIH}$ and two gene-related peptide sequences, i.e. quail GnIHRP-1 and GnIH-RP-2 (Satake et al. 2001). We previously identified endogenous GnIH and GnIH-RP-2 encoded 


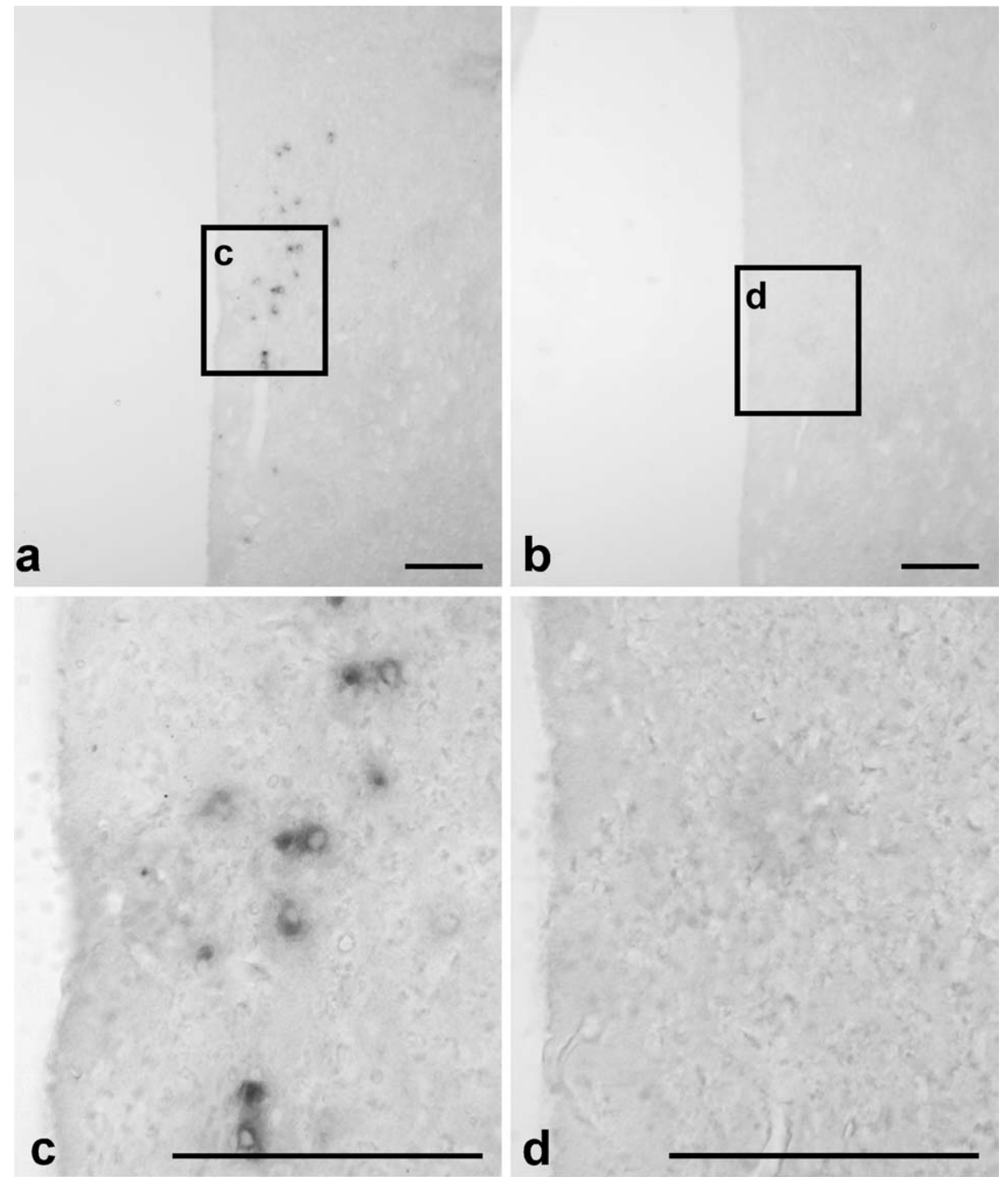

Figure 5 Cellular localization of sparrow GnlH mRNA in the brain. The expression of sparrow GnlH mRNA was localized by in situ hybridization. Distribution of sparrow GnlH mRNA in the PVN as observed in a frontal brain section of the sparrow brain $(\mathrm{a}, \mathrm{c})$. Lack of hybridization of sparrow GnlH mRNA by the sense probe (control) is evident $(b, d)$. The square boxes in (a) and (b) are enlarged in (c) and (d) respectively. Scale bars represent $100 \mu \mathrm{m}$.

in the quail GnIH precursor polypeptide (Tsutsui et al. 2000, Satake et al. 2001). Although quail endogenous GnIH-RP-1 remains to be identified, the mammalian counterpart of GnIH-RP-1 has been identified as bovine endogenous RFamide-related peptide-1 (RFRP-1), SLTFEEVKDWAPKIKMNKPVVNKMPPSAANLPLRF$\mathrm{NH}_{2}$ (Fukusumi et al. 2001). Based on these present and previous findings, we predicted sparrow endogenous GnIH and GnIH-RPs boxed in Fig. 3. Because the C-terminal Gly residue of each peptide is known to be a typical amidation signal, the C-terminal cleavage site of sparrow GnIH and GnIH-RPs may be the same as that of quail GnIH and GnIH-RPs (Fig. 3, Tsutsui et al. 2000, Satake et al. 2001). On the other hand, sparrow GnIH may be cleaved by the same $\mathrm{N}$-terminal processing of quail $\mathrm{GnIH}$; consequently sparrow and quail GnIHs include the same N-terminal structure (Fig. 3). Based on the N-terminal structure of bovine RFRP-1 (Fukusumi et al. 2001), the N-terminal cleavage of sparrow GnIHRP-1 may occur at a single basic amino acid $\mathrm{Arg}^{58}$ by the same processing mechanism of RFRP-1. Sparrow GnIHRP-2 may be cleaved at a single basic amino acid Arg ${ }^{136}$ by the same processing mechanism of quail GnIH-RP-2 (Satake et al. 2001), although the length of sparrow 

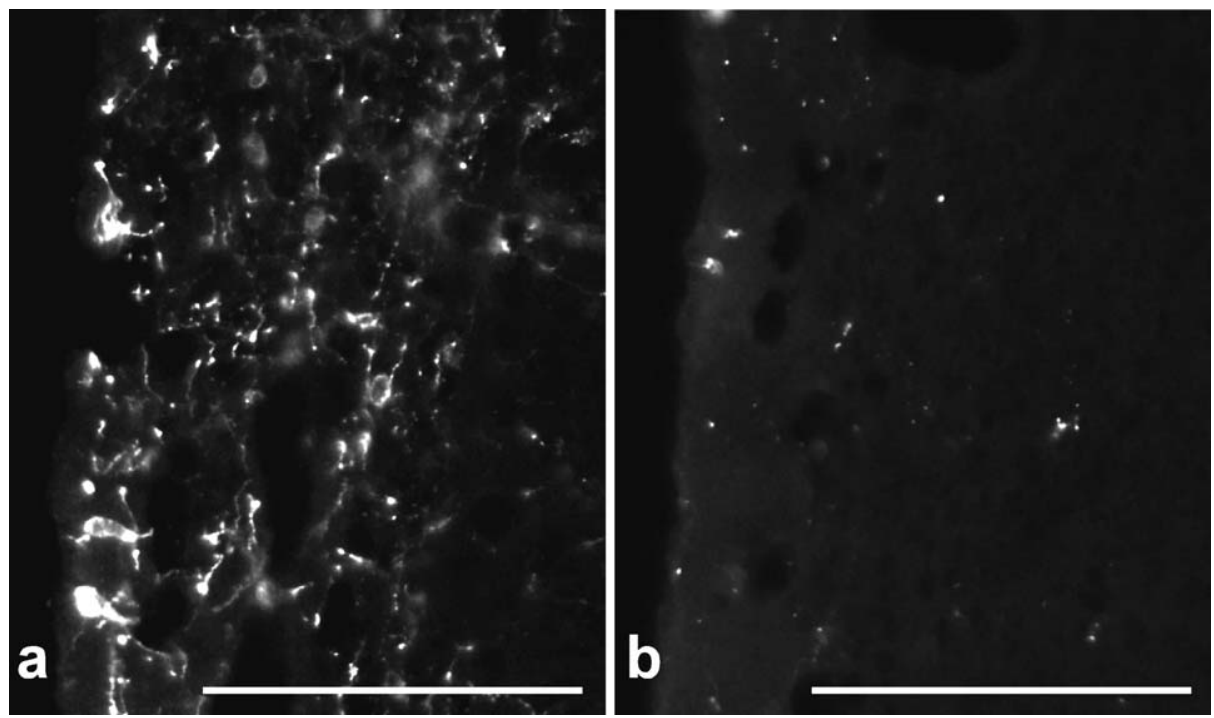

Figure 6 Cellular localization of sparrow GnlH in the brain. Immunohistochemical staining in a frontal brain section was carried out with antiserum against quail GnIH. Immunoreactive cell bodies and fibers were observed in the PVN (a). Preincubation of the antiserum with a saturating concentration of synthetic GnlH was carried out as the control (b). Scale bars represent $100 \mu \mathrm{m}$.

GnIH-RP-2 is longer than that of quail GnIH-RP-2 (Fig. 3). Figure 3 shows the comparison of the $\mathrm{GnIH}$ precursor polypeptide structure among the sparrow, quail and chicken. The homology of the structure of GnIH precursor polypeptide was low (approximately 66\%) between the sparrow and quail and high (approximately 95\%) between the quail and chicken. In these three birds, however, the C-terminal structures of GnIH, GnIHRP-1 and GnIH-RP-2 were identical respectively. As summarized in Fig. 4, all GnIH and GnIH-RPs included an LPXRF- $\mathrm{NH}_{2}$ sequence $(\mathrm{X}=\mathrm{L}$ or $\mathrm{Q}$ ) at their $\mathrm{C}$-termini in the sparrow, quail and chicken. On the other hand,

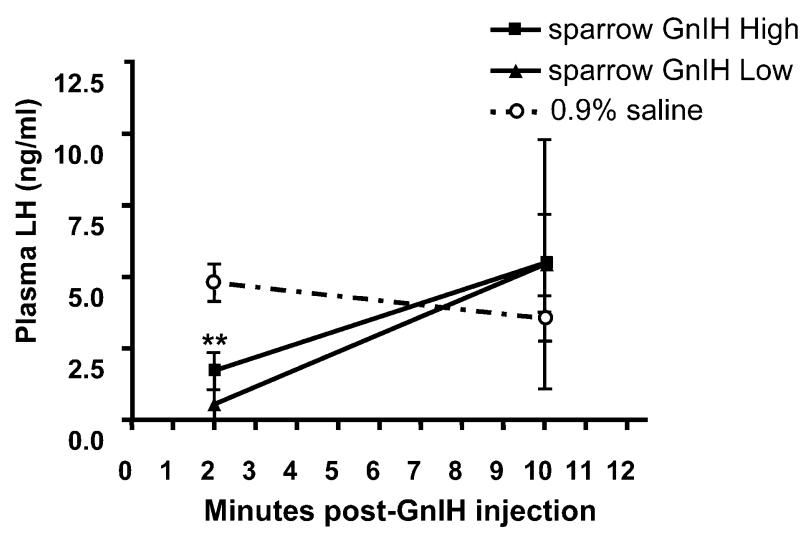

Figure 7 The effects of putative sparrow GnlH on plasma $\mathrm{LH}$ in field-injected, breeding Gambel's white-crowned sparrows. Plasma $\mathrm{LH}$ was lower in the $\mathrm{GnlH}$-injected group at 2 min but at no other time. ${ }^{* *} P<0.01 \mathrm{GnlH}$ high vs vehicle by ANOVA, followed by Fisher's PLSD for post-hoc analysis. the homology of each peptide was low (GnIH: 75\%; GnIH-RP-1: 73\%; GnIH-RP-2: 61\%) between the sparrow and quail and high (GnIH: 92\%; GnIH-RP-1: 97\%; GnIH-RP-2: 100\%) between the quail and chicken. This difference may be due to phylogeny of galliformes and passeriformes. Notwithstanding such a difference in sequence homology, the presence of $\mathrm{GnIH}$ and GnIHRPs in the brain may be an evolutionarily conserved property in birds. Identification of mature endogenous sparrow $\mathrm{GnIH}$ and $\mathrm{GnIH}-\mathrm{RPs}$ is now in progress.

Identification of the cells expressing sparrow $\mathrm{GnIH}$ mRNA in the brain must be taken into account when studying the action of neuropeptides. In this study, we therefore characterized the site showing the expression of sparrow GnIH mRNA by in situ hybridization. The sparrow GnIH mRNA expression was localized only in the PVN in the hypothalamus of the white-crowned sparrow. The control study using a sense RNA probe resulted in a complete absence of the sparrow GnIH mRNA expression, suggesting the validity of the in situ hybridization technique. The GnIH-like immunoreactive cells were also observed in the PVN and their fibers were distributed in the hypothalamus including the PVN. No positive signals were observed by immunohistochemistry in this study following pre-absorption experiments with an excess amount of synthetic GnIH. These results are in accord with the expressions of GnIH mRNA and GnIH in the quail (Tsutsui et al. 2000, Satake et al. 2001, Ubuka et al. 2003, Ukena et al. 2003). In our previous study (Bentley et al. 2003), the terminals of PVN neurons containing sparrow $\mathrm{GnIH}$ were localized in the ME and other brain regions in the sparrow brain. In addition, 
Bentley et al. (2003) reported that GnIH-containing PVN neurons were larger in the sparrow at the termination of the breeding season than at other times.

In summary, we have revealed the structure of $\mathrm{GnIH}$ precursor cDNA and the localization of its transcript in the white-crowned sparrow, one of the most intensively studied seasonally breeding birds. The identified sparrow GnIH precursor cDNA encoded putative sparrow $\mathrm{GnIH}$ and GnIH-RPs including the LPXRF (X=L or Q) motif at their C-termini. The expressions of sparrow $\mathrm{GnIH}$ mRNA and GnIH were localized in the PVN. Injection of the synthetic peptide caused a rapid decrease in plasma LH in free-living, breeding white-crowned sparrows, thus confirming its biological relevance. Further study is required to establish the exact physiological role of GnIH in this seasonally breeding bird, although it is clear that treatment with synthetic sparrow GnIH rapidly and transiently suppresses LH in field-injected white-crowned sparrows. Taken together, our series of injection experiments implies that sparrow GnIH may play an important role in the regulation of reproductive activity by inhibiting gonadotropin release in the white-crowned sparrow, a wild avian species. The present findings provide a basis for future study of the action of GnIH and its physiological significance in the seasonally breeding bird.

\section{Funding}

This work was supported in part by Grants-in-Aid for Scientific Research from the Ministry of Education, Science and Culture, Japan (1240233, 12894021, 13210101 and 15207007 to K T, and 15770040 to K U); NIH, USA (R01 MH065974 to J C W); and NSF, USA (OPP-9911333 to J C W) This work was an international joint project. There is no conflict of interest that would prejudice the impartiality of the research described in this article.

\section{References}

Bentley GE, Perfito N, Ukena K, Tsutsui K \& Wingfield JC 2003 Gonadotropin-inhibitory peptide in song sparrows (Melospiza melodia) in different reproductive conditions, and in house sparrows (Passer domesticus) relative to chicken-gonadotropin-releasing hormone. Journal of Neuroendocrinology 15 794-802.

Dawson A \& Goldsmith AR 1982 Prolactin and gonadotrophin secretion in wild starlings (Sturnus vulgaris) during the annual cycle and in relation to nesting, incubation, and rearing young. General and Comparative Endocrinology 48 213-221.

Dawson A, King VM, Bentley GE \& Ball GF 2001 Photoperiodic control of seasonality in birds. Journal of Biological Rhythms $\mathbf{1 6}$ 365-380.

Farner DS 1964 The photoperiodic control of reproductive cycles in birds. American Scientist 52 139-156.

Farner DS 1975 Photoperiodic controls in the secretion of gonadotropins in birds. American Zoologist 15 (Suppl) 117-135.
Farner DS \& Mewaldt LR 1955 The natural termination of the refractory period in the white-crowned sparrow. Condor $\mathbf{5 7}$ 112-116.

Follett BK, Scanes CG \& Cunningham FJ 1972 A radioimmunoassay for avian luteinizing hormone. Journal of Endocrinology 52 359-378.

Fukusumi S, Habata Y, Yoshida H, Iijima N, Kawamata Y, Hosoya M, Fujii R, Hinuma S, Kitada C, Shintani Y et al. 2001 Characteristics and distribution of endogenous RFamide-related peptide-1. Biochimica et Biophysica Acta 1540 221-232.

King JR, Follett BK, Farner DS \& Morton ML 1966 Annual gonadal cycles and pituitary gonadotropins in Zonotrichia leucophrys gambelii. Condor 68 476-487.

Koda A, Ukena K, Teranishi H, Ohta S, Yamamoto K, Kikuyama S \& Tsutsui K 2002 A novel amphibian hypothalamic neuropeptide: isolation, localization and biological activity. Endocrinology 143 411-419.

Nicholls TJ, Goldsmith AR \& Dawson A 1988 Photorefractoriness in birds and comparison with mammals. Physiological Reviews 68 133-176.

Satake H, Hisada M, Kawada T, Minakata H, Ukena K \& Tsutsui K 2001 Characterization of a cDNA encoding a novel avian hypothalamic neuropeptide exerting an inhibitory effect on gonadotropin release. Biochemical Journal 354 379-385.

Sawada K, Ukena K, Kikuyama S \& Tsutsui K 2002a Identification of a cDNA encoding a novel amphibian growth hormone-releasing peptide and localization of its transcript. Journal of Endocrinology 174 395-402.

Sawada K, Ukena K, Satake H, Iwakoshi E, Minakata H \& Tsutsui K $2002 b$ Novel fish hypothalamic neuropeptide. Cloning of a cDNA encoding the precursor polypeptide and identification and localization of the mature peptide. European Journal of Biochemistry 269 6000-6008.

Tsutsui K, Saigoh E, Ukena K, Teranishi H, Fujisawa Y, Kikuchi M, Ishii S \& Sharp PJ 2000 A novel avian hypothalamic peptide inhibiting gonadotropin release. Biochemical and Biophysical Research Communications 275 661-667.

Ubuka T, Ueno M, Ukena K \& Tsutsui K 2003 Developmental changes in gonadotropin-inhibitory hormone in the Japanese quail (Coturnix japonica) hypothalamo-hypophysial system. Journal of Endocrinology 178 311-318.

Ukena K \& Tsutsui K 2001 Distribution of novel RFamide-related peptide-like immunoreactivity in the mouse central nervous system. Neuroscience Letters 300 153-156.

Ukena K, Kohchi C \& Tsutsui K 1999 Expression and activity of $3 \beta$-hydroxysteroid dehydrogenase $/ \Delta^{5}-\Delta^{4}$-isomerase in the rat Purkinje neuron during neonatal life. Endocrinology 140 805-813.

Ukena K, Ubuka T \& Tsutsui K 2003 Distribution of a novel avian gonadotropin-inhibitory hormone in the quail brain. Cell and Tissue Research 312 73-79.

Wingfield JC \& Farner DS 1978 The annual cycle of plasma irLH and steroid hormones in feral populations of the white-crowned sparrow, Zonotrichia leucophrys gambelii. Biology of Reproduction 19 1046-1056.

Wingfield JC \& Farner DS 1993 Endocrinology of reproduction in wild species. In Avian Biology, edn 9, pp 163-327. Eds DS Farner, JR King \& KC Parkes. New York: Academic Press.

Wingfield JC \& Silverin B 2002 Ecophysiological studies of hormone-behavior relations in birds. In Hormones, Brain and Behavior, edn 2, pp 587-647. Eds DW Pfaff, AP Arnold, AM Etgen, SE Fahrbach \& RT Rubin. Amsterdam: Elsevier Science.

Wingfield JC, Crim JW, Mattocks PW Jr \& Farner DS 1979 Responses of photosensitive and photorefractory male white-crowned sparrows (Zonotrichia leucophrys gambelii) to synthetic mammalian luteinizing hormone releasing hormone (syn-LHRH). Biology of Reproduction 21 801-806.

Received 19 March 2004

Accepted 5 April 2004 